Лasvax T.Б., аспірант

\title{
ПРОБЛЕМНІ СЛІДЧІ СИТУАЦІЇ ДОСУДОВОГО РОЗСЛІДУВАННЯ МАСОВИХ ЗАВОРУШЕНЬ
}

\begin{abstract}
Анотація. Стаття присвячена дослідженню слідчих ситуацій, які виникають на різних етапах досудового розслідування масових заворушень. Встановлено, що на початковому етапі розслідування виникають переважно проблемні ситуації - ситуації конфліктів, тактичного ризику. Зазвичай кожна слідча ситуація передбачає певний алгоритм дій слідчого. Особливості алгоритмів розслідування створюють такі слідчі дії: процесуальне затримання й різноманітні види допитів, огляд місця події, пред’явлення для впізнання, призначення різноманітних експертиз.

Ключові слова: масові заворушення, досудове розслідування, слідчі ситуації, слідчі дії, алгоритм дій слідчого, конфліктна ситуація, ситуація тактичного ризику.
\end{abstract}

Постановка пробллеми. Останнім часом правоохоронні органи України мають справу не лише зі зростанням злочинності, а й з появою нових її форм, удосконаленням відомих раніше способів скоєння злочинів, активною протидією розслідуванню з боку зацікавлених у цьому осіб. На жаль, до нових умов боротьби зі злочинністю вітчизняні правоохоронні структури адаптуються вкрай повільно. Це можна простежити на прикладі вивчення питання боротьби з таким видом злочинів, як масові заворушення.

Засоби й методи, які застосовуються правоохоронними органами у протидії масовим заворушенням, не завжди дієві, а інколи й малоперспективні для встановлення фактичних обставин скоєння злочину й покарання винних осіб. Не можна заперечувати й наявність типових помилок, яких припускаються співробітники правоохоронних органів під час досудового розслідування цього виду злочинів. Такого висновку дають змогу дійти офіційні дані прокурорської та судової статистики. Так, відповідно до Єдиного звіту про кримінальні правопорушення в Україні за 2013 р. було обліковано кримінальних правопорушень (злочинів): за ознаками ст. 294 КК - 2, з яких жодного не було спрямовано до суду з обвинувальним актом; закрито провадженням - 2. За 2014 р. обліковано кримінальних правопорушень (злочинів): за ознаками ст. 294 КК - 148, з яких: спрямовано до суду з обвинувальним актом - 10; закрито провадженням - 71, залишилось без прийняття остаточного рішення КК - 95 [1]. У 2015 р. в Україні обліковано 22 кримінальні правопорушення щодо вказаної категорії злочинів, з яких повідомлено особам про підозру лише у 14; у 2016 році ці показники становлять 9 i 1 відповідно. У 2017 році в Україні обліковано 8 кримінальних правопорушень щодо вказаної категорії злочинів, $з$ яких повідомлено особам про підозру - 3 [2]. Станом на жовтень 2018 року обліковано 10 кримінальних правопорушень про масові заворушення, повідомлено особам про підозру - 2, спрямовано до суду з обвинувальним актом - 1 [3]. Ці та інші дані переконливо свідчать про те, що кількість кримінальних проваджень, порушених за ознаками злочину, передбаченого ст. 294 КК України, у декілька разів перевищує кількість проваджень про масові заворушення, за результатами розслідування яких до суду було спрямовано обвинувальні акти. Більшість кримінальних проваджень за ст. 294 КК України або закриваються з різних підстав, або залишаються без прийняття остаточного рішення, що свідчить про низьку ефективність протидії масовим заворушенням правоохоронної і судової системи та необхідність ії підвищення [4, с. 128].

Аналіз дослідження проб̆леми. Значна теоретична актуальність дослідження питань досудового розслідування масових заворушень зумовлена істотною практичною значимістю, оскільки ця тема має прямий вихід на питання підвищення ефективності кримінального судочинства загалом і досудового розслідування конкретних видів злочинів зокрема. Варто вказати на те, що така проблема постала не лише в Україні, а є відомою й для інших країн так названого ближнього та далекого зарубіжжя. Різні аспекти здійснення досудового розслідування масових заворушень у цілому останнім часом були розглянуті в дисертаціях та монографіях, підготовлених вітчизняними й зарубіжними науковцями. Зокрема, В.Г. Єнгібаряном була захищена докторська дисертація «Розслідування масових заворушень: теоретичні, організаційні та методико-криміналістичні основи» (2015). Вітчизняним науковцем П.В. Шалдирваном захищено кандидатську дисертацію на тему «Методика розслідування масових заворушень» (2005), у 2017 р. іншим вітчизняним науковцем О.П. Кузьменко була захищена кандидатська дисертація «Початковий етап розслідування масових заворушень». Проблеми, пов'язані 3 розслідуванням масових заворушень, були предметом дослідження в монографічних працях і наукових посібниках В.Г. Єнгібаряна, О.М. Багмета, В.В. Бичкова, М.А. Погорецького, О.Ю. Татарова, Д.Б. Сергеєвої, М.С. Цуцкірідзе та ін. Певну кількість наукових статей, присвячених окремим проблемам досудового розслідування масових заворушень, підготовлено вітчизняним науковцем В.I. Бояровим. У цих та інших наукових працях провідних вітчизняних і зарубіжних учених і практиків порушувались питання організації й планування досудового розслідування і певною мірою висвітлювались проблеми наявних на час досудового розслідування слідчих ситуацій. Проте з огляду на проблемний характер слідчих ситуацій, здебільшого таких, що мають конфліктний характер, вважаємо за необхідне розглянути ці проблеми.

Метою статті $\epsilon$ з'ясування питання щодо видів слідчих ситуацій, які виникають у процесі досудового розслідування масових заворушень, визначення причин і характеру можливих конфліктів між учасниками та пошук шляхів виходу 3 конфліктних ситуацій під час досудового розслідування.

Виклад основного матеріалу. Масові заворушення - особливий конгломерат різноманітних злочинних діянь. До їх складу можуть входити такі самостійні злочини, як насильство 
над особою, погроми, підпали, знищення майна, захоплення будівель або споруд, насильницькі виселення громадян, опір представникам влади із застосуванням зброї або інших предметів, які використовувалися як зброя, а в кримінальному законодавстві вказані діяння подібного роду разом називаються масовими заворушеннями, тобто сукупністю певних злочинів, злочинних дій, включаючи їх організацію [5, с. 28]. В.I. Ткаченко справедливо звертає увагу на те, що серйозні наслідки злочинів, які вчиняються під час масових заворушень, не просто завдають шкоди громадській безпеці, а буквально підривають іï в масштабах всієї країни [6, с. 4.], а тому посягають на основи державності. Масові заворушення небезпечні тим, що їх учасники застосовують насильство в будь-якій формі, знищують і пошкоджують майно, застосовують вогнепальну зброю, вибухові речовини і вибухові пристрої. Тим самим вони ставлять під загрозу життя невизначеного кола людей. Крім того, під час масових заворушень чиниться озброєний опір представникам влади. Отже, ці злочини становлять небезпеку для всього суспільства загалом, тобто їх безпосереднім об'єктом є суспільні відносини, що забезпечують загальну безпеку громадян як членів суспільства [7, с. 8].

За своєю суттю масові заворушення є публічними заходами, проте такими, що перебувають за межами закону і становлять суспільну небезпеку. Фахівці в галузі кримінального права звертають увагу на те, що масовими заворушеннями вважають порушення громадського порядку невизначеною кількістю людей - натовпом. Об'єктивно масові заворушення проявляються у насильствах над особою; погромах; підпалах; вибухах; знищеннях майна; опорі представникам влади із застосуванням зброї чи інших предметів, які використовуються як зброя [8, с. 451]. Традиційно аналізу складу кримінального правопорушення передує вивчення його об'єкта, що дає змогу не лише з'ясувати соціально-юридичну сутність конкретного злочину, а й виступає вихідною передумовою для правильної кваліфікації злочинів, а отже, спрямовує на розроблення криміналістичних засобів як знарядь для встановлення фактичних обставин скоєння цього діяння.

Успішне виконання завдань кримінального провадження потребує встановлення під час досудового розслідування масових заворушень усіх обставин, що підлягають доказуванню у кримінальних провадженнях щодо цієї категорії злочинів. Відповідно до вимог ст. 91 КПК України у кримінальному провадженні про масові заворушення підлягають доказуванню: подія масових заворушень (час, місце, спосіб та інші обставини вчинення кримінального правопорушення); винуватість особи у вчиненні організації масових заворушень, що супроводжується насильством над особою, підпалами, знищенням майна, захопленням будівель або споруд, насильницьким виселенням громадян, опором представникам влади із застосуванням зброї або інших предметів, які використовуються як зброя, а також активна участь у масових заворушеннях; форма вини, мотив і мета скоєння злочину; вид і розмір шкоди, завданої злочином, а також розмір процесуальних витрат; обставини, що впливають на ступінь тяжкості скоєного злочину, характеризують особу обвинуваченого, обтяжують чи пом'якшують покарання, які виключають кримінальну відповідальність або є підставою закриття кримінального провадження; обставини, що є підставою для звільнення від кримінальної відповідальності або покарання [9, с. 28].
Під час розслідування масових заворушень необхідно визначити вичерпний перелік обставин, що підлягають доказуванню, не тільки з урахуванням загального вчення про предмет доказування, але і з урахуванням особливостей його криміналістичних ознак. Останнє досягається шляхом аналізу масових заворушень 3 криміналістичних позицій. Все це визначає методи й принципи виявлення, збирання, систематизації, обробки інформації щодо закономірностей організації та здійснення розслідування масових заворушень.

Досудове розслідування масових заворушень за своєю суттю $є$ пізнавальним процесом, своєрідність якого полягає в тому, що воно здійснюється у формі доказування. Складність завдань 3 досудового розслідування цієї категорії кримінальних правопорушень потребує застосування різноманітних шляхів та засобів виконання розумових завдань. У вирішенні цих питань особливу роль відіграють такі складники діяльності слідчого, прокурора, як алгоритмізація і творчий елемент. Плануючи проведення досудового розслідування, підготовку й проведення окремих слідчих (розшукових), негласних слідчих (розшукових) дій, інших заходів слідчий має застосовувати свої знання у конкретній слідчій ситуації. До того ж він оперує двома потоками інформації: один є зовнішнім, тобто таким, що надходить під час вивчення обстановки і обставин злочину; другий - внутрішній - це знання, що містяться в пам'яті слідчого, отримані ним у процесі навчання і практичної роботи [10, с. 173].

Більшість елементів поведінки слідчого незалежно від рівня розумової активності регулюється певними штампами, «автоматизмами», здобутими в результаті життєвого і професійного досвіду. Крім того, слідчий не в змозі уникнути одноманітної технічної роботи, зокрема, пов'язаної з неухильним дотриманням передбаченої законом процесуальної форми. У таких випадках криміналістичні алгоритми дають змогу виконувати всі необхідні процесуальні умови, досягати поставленої мети та істотно зекономити фізичні, психологічні ресурси слідчого, розвиваючи його алгоритмічне мислення [11, с. 236].

Нині в діяльності слідчого, прокурора все частіше постає проблема алгоритмізації дій слідчого з досудового розслідування конкретних видів злочинів. На це звертають увагу і науковці, які вважають, що необхідність розроблення алгоритмів роботи слідчого зумовлюється кардинальним оновленням кримінального процесуального законодавства та кадрової системи органів досудового розслідування. У цьому аспекті ми підтримуємо думку вітчизняного науковця В.А. Журавля, який наголошує на тому, що метою алгоритмізації є стимулювання ділової активності слідчого. Саме алгоритми в різноманітних типових слідчих ситуаціях здатні забезпечити швидкість прийняття рішення з урахуванням усіх без винятку рекомендацій криміналістики і вимог чинного законодавства. За їх допомогою розумова діяльність слідчого істотно полегшується, не втрачаючи при цьому своїх творчих засад [12]. На нашу думку, доцільність розроблення алгоритмів найбільш очевидна у випадках недостатньої кваліфікації кадрів, яка натепер має місце в Україні, а також за наявності складнощів, які виникають у зв'язку із широким спектром евристичних рішень, котрі необхідно приймати слідчому під час досудового розслідування масових заворушень.

Уже нині ідеї алгоритмізації поступово прокладають собі шлях: методичні рекомендації щодо розслідування злочинів, використання технічних засобів для формування доказової 
бази стають дедалі конкретнішими і чіткішими, починають базуватись не лише на інтуїтивно узагальненому досвіді діяльності слідчих. Останніми роками спостерігається тенденція до програмування аналізу значної кількості слідчих ситуацій. При цьому можна стверджувати, що цей процес є об'єктивно зумовленим, адже такі рекомендації не мають бути абстрактними, а мають ураховувати відповідну видову спрямованість злочинів і висвітлювати найбільш складні аспекти проблеми. Під час комплексного аналізу кожного типу злочинів можна побудувати найбільш конструктивний алгоритм використання відповідних сил та засобів [13].

Інформаційною базою для організації розслідування масових заворушень можуть слугувати конкретні слідчі ситуації, які можуть бути найрізноматнішими, що й зумовлює різний підхід у визначенні лінії дій слідчого, у виборі кола й послідовності проведення невідкладних слідчих дій, форм взаємодії слідчого iз оперативно-розшуковими й судово-експертними підрозділами. Характер конкретної слідчої ситуації, яка виникає під час досудового розслідування масових заворушень, визначається такими обставинами, як: стихійність виникнення, що потребує розслідування; значна кількість скоєних злочинів; масштабність і висока динамічність процесу розслідування, множинність матеріальних слідів та особливості їх утворення; підвищена мінливість слідчої ситуації; дефіцит часу для прийняття й здійснення органами розслідування процесуальних і тактичних рішень; необхідність застосування особливого порядку систематизації інформації, яка надходить, і іï негайного використання; протидія розслідуванню [14, с. 173-175].

Зазвичай під час досудового розслідування масових заворушень може виникати велика різноманітність слідчих ситуацій: від начебто простих на перший погляд до надскладних, зокрема конфліктних, ситуацій тактичного ризику, «тупикових» та ін. Виникнення таких проблемних ситуацій зумовлене відсутністю або суттєвим недоліком необхідних для доказування обставин, встановлення яких передбачено ч. 1 ст. 91 КПК України. Відомий криміналіст Л.Я. Драпкін звертає увагу на те, що в проблемних ситуаціях можливі джерела ще не виявленої додаткової інформації, котра могла б усунути проблемну ситуацію, носять латентний характер і далеко не кожний слідчий може їх виявити й успішно використовувати. Тим самим труднощі містяться у виникненні логіко-інформаційних бар'єрів, пов'язаних $з$ повною або частковою відсутністю відомостей про різноманітні обставини предмета доказування й насамперед про особу злочинця. У процесі досудового розслідування масових заворушень можуть виникати і так звані «тупикові» слідчі ситуації. Окремі проблемні ситуації мають настільки гострий і майже невирішуваний характер, що виникає необхідність у застосуванні інших методів. Відмінність цієї ситуації від ситуації проблемної полягає, по-перше, в особливій складності встановлення й доказування вини особи, що скоїла злочин, а по-друге, в тому, що подібні ситуації долаються за допомогою методу інтуїції, а не методу висунення й перевірки версій. У тупикових ситуаціях інтуїтивні здогадки, спрямовані на їх вирішення, не висуваються, а раптово виникають у свідомості слідчого і вже потім перевіряються [15, с. 118.].

Інколи під час розслідування масових заворушень можуть виникати й конфліктні ситуації, зміст яких становлять перешкоди тактико-психологічного і тактико-інформаційного характеру. Такі труднощі зазвичай виникають у процесі активної про- тидії організаторів і активних учасників масових заворушень, а також недобросовісних свідків і навіть окремих потерпілих намірам слідчого, спрямованим на всебічне і повне розслідування злочину. Також для досудового розслідування масових заворушень $€$ характерними так звані ситуації тактичного ризику, які виникають у процесі проведення огляду місця події, під час затримання організаторів й активних учасників масових заворушень, а також під час проведення окремих слідчих (розшукових) дій - допиту, обшуку, якщо вони проводяться без достатньої підготовки і врахування негативних дій з боку учасників масових заворушень та осіб, що стоять за ними.

Аналіз практики досудового розслідування масових заворушень свідчить про те, що проблемні ситуації найчастіше виникають на початковому етапі розслідування. Зокрема, можливими є такі слідчі ситуації:

1. Особи, що безчинствують, перебувають у натовпі, ними вчиняються погроми, підпали, руйнування або інші суспільно небезпечні дії, але дані про організаторів і учасників відсутні.

2. Масові заворушення припинилися, проте відомості про їх організаторів і активних учасників ще не досить повні.

3. Масові заворушення припинилися іє відомості про їх організаторів й активних учасників, місцезнаходження яких невідоме.

За наявності першої типової слідчої ситуації зусилля спрямовуються на припинення й локалізацію масових заворушень, виявлення їх активних учасників, виявлення свідків і потерпілих, виявлення і фіксацію предметів та слідів. Друга типова слідча ситуація передбачає необхідність збирання доказів щодо всіх організаторів та активних учасників масових заворушень, встановлення конкретних фактів їх злочинної діяльності й вжиття заходів до їх затримання й обрання запобіжних заходів. У разі виникнення третьої типової ситуації головна увага має приділятися насамперед встановленню місця перебування осіб, що причетні до цього кримінального правопорушення, їх затримання й обрання запобіжних заходів. В усіх цих підгрупах проблемних слідчих ситуацій основні зусилля слідчого мають бути спрямовані на відшукання, закріплення, дослідження й оцінку інформації, що підтверджує вчинення саме масового заворушення, а не інших окремих злочинів, що можуть входити до складу таких протиправних дій.

Кожній слідчій ситуації відповідає алгоритм слідчих (розшукових) та негласних слідчих (розшукових) дій з їх вирішення. Особливості алгоритмів розслідування на початковому етапі утворюють такі слідчі (розшукові) дії: процесуальне затримання й різновидові допити одночасно значної кількості підозрюваних у вчиненні масових заворушень; огляд декількох місць події; допити значної кількості свідків і потерпілих; пред'явлення для впізнання; освідування учасників подій, до того ж як підозрюваних, так і потерпілих; призначення й проведення великої кількості судових експертиз. Алгоритми розслідування на наступному етапі включають обшуки, слідчі експерименти, одночасні допити декількох осіб та ін.

Висновки. Розслідуючи кримінальне провадження про масові заворушення, слідчий має встановити проблемність слідчої ситуації і з'ясувати можливість їі вирішення, звернутися до криміналістичних рекомендацій технічного, тактичного, методичного й організаційного характеру, скласти план досудового розслідування, де передбачити відповідний алгоритм дій. 


\section{Jimepamypa:}

1. Статистична інформація за 2013-2015 роки. Генеральна прокуратура України. URL: http://www.gp.gov.ua

2. Статистична інформація за 2017 рік. Генеральна прокуратура України. URL: http://www.gp.gov.ua

3. Статистична інформація за 2018 рік. Генеральна прокуратура України. URL: http://www.gp.gov.ua

4. Дячкін М.О. Організація злочину «масові заворушення». Юридичний науковий електронний журнал. № 2/2017. С. 128-130.

5. Енгибарян В. Объект и предмет криминалистической концепции расследования массовых беспорядков. URL: http://ysu.am/ files/03V_Engibaryan_r.pdfC.26-34

6. Ткаченко В.И. Преступления против общественной безопасности: учебное пособие / Отв. ред.: Здравомыслов Б.В. Москва: РИО ВЮЗИ, 1984. $81 \mathrm{c}$.

7. Багмет А.М. Массовые беспорядки как элемент политического терроризма и экстремизма. Особенности расследования преступлений экстремистской и террористической направленности: сб. материалов научно-практического семинара (Ростов-на-Дону, 24-25 мая 2012 г.). Москва: ИПК СК РФ, 2012. С. 7-12.

8. Коржанський М.Й. Кваліфікація злочинів: навчальний посібник. Вид. 2-ге. Київ: Атіка, 2002. 640 с.

9. Погорецький М.А., Татаров О.Ю., Сергеєва Д.Б. та ін. Розслідування масових заворушень: навч. посібник. Київ: ВД «Дакор», 2014. 140 с.

10. Томин С.В. Використання слідчим комп’ютерних баз даних під час планування розслідування злочинів. Правова держава. № 13. 2011. C. 173-178.

11. Соколенко М.О. Алгоритмізація і творчий підхід у тактиці допиту. Питання боротьби зі злочинністю. Випуск 29'2015. С. 235-242.

12. Журавель В.А. Проблеми формалізації слідчої діяльності. Реформування судових і правоохоронних органів України: проблеми та перспективи: матеріали наук.-практ. конф., 14 трав. 2010 р. Харків: Одіссей, 2010. С. 356-357.

13. Цехан Д.М. Проблеми протидії злочинності в інформаційному суспільстві. Актуальні проблеми взаємодії оперативних та слідчих підрозділів у протидії організованій злочинній діяльності: матеріали Всеукр. наук.-практ. конф. (м. Одеса, 18 квіт. 2008 р.). Одеса: ОДУВС, 2008. С. 250-253.

14. Енгибарян В.Г. Расследование массовых беспорядков: теоретические, организационные, методико-криминалистические основы (по материалам Республики Армения): автореф. дис. ...д-ра юрид. наук: 12.00.09. Москва, 2015. 422 с.
15. Драпкин Л.Я. Ситуационный подход в криминалистической теории и практической деятельности правоохранительных органов. Проблемы современной криминалистики и основные направления ее развития в XXI веке: материалы Международной научно-практической конференции (6 октября 2017 г.). Екатеринбург: Издательский дом Уральского гос. юрид. у-та, 2017. С. 115-131.

Ламах Т. Б. Проблемные следственные ситуации досудебного расследования массовых беспорядков

Аннотация. Статья посвящена исследованию следственных ситуаций, которые возникают на различных этапах досудебного расследования массовых беспорядков. Установлено, что на первоначальном этапе расследования возникают преимущественно проблемные ситуации - ситуации конфликтные, тактического риска. Как правило, каждая следственная ситуация предполагает определенный алгоритм действий следователя. Особенности алгоритмов расследования создают такие следственные действия: процессуальное задержание и различные виды допросов, осмотр места происшествия, предъявление для опознания, назначение различных экспертиз.

Ключевые слова: массовые беспорядки, досудебное расследование, следственные ситуации, следственные действия, алгоритм действий следователя, конфликтная ситуация, ситуация тактического риска.

Lamakh T. Problem inquisitional situations of pre-trial investigation of riots

Summary. The article deals with the research of inquisitional situations that arise up on the different stages of pre-trial investigation of riots. It is set that on the primary stage of investigation there are mainly problem situations - the situations of conflict, tactical risk. As a rule, every inquisitional situation supposes the certain algorithm of actions of investigator. The features of algorithms of investigation create such inquisitional actions: judicial detention and different types of interrogations, examination of site of occurrence, producing for identification, setting of different.

Key words: riots, pre-trial investigation, inquisitional situations, inquisitional actions, algorithm of actions of investigator, conflict situation, situation of tactical risk. 